\title{
KAJIAN KELAYAKAN USAHA PEMBESARAN IKAN MAS (Cyprinus carpio) DALAM KERAMBA JARING APUNG DIWADUK CIRATA KABUPATEN CIANJUR JAWA BARAT
}

\author{
Oleh \\ Asep Ahmad Subagio \\ Dosen Jurusan Penyuluhan Perikanan,Sekolah Tinggi Perikanan
}

\begin{abstract}
ABSTRAK
Pengkajian kelayakan usaha pembesaran ikan mas (cyprinus carpio) dalam keramba jaring apung telah di lakukan bulan Oktober sampai dengan Nopvember 2008 di Waduk Cirata Kabupaten Cianjur. Jumlah responden sebanyak 15 orang terdiri dari pemilik usaha pembesaran ikan mas dalam kantong jaring apung sebanyak 2 kantong sampai dengan 20 kantong .Pengkajian ini betujuan untuk menghitun kelayakan usaha pembesaran ikan mas dalam keramba jaring apung. Hasil pengkajian bertujuan bahwa usaha pembesaran ikan mas dalam keramba dilihat dari perhitungan $\mathrm{R} / \mathrm{C}$ ratio,PP dan IRR menghasilkan angka-angka yang menunjukan bahwa usaha tersebut masih layak untuk di usahakan.
\end{abstract}

Kata Kunci : Ikan Mas, Jaring Apung, Waduk Cirata, R/C ratio, PP, IRR

\section{PENDAhuluan}

\section{Latar Belakang}

Luas peraiaran umum Indonesia diperkirakan lebih dari 50 juta ha, terdiri dari perairan rawa 39,4 juta ha, perairan sungai beserta lebarnya 11,95 ha, serta danau alam dan danau buatan (waduk) tercatat seluas 2,1 juta ha (Rochdianto, 1986). Waduk adalah salah satu sumberdaya periran umum yang memiliki potensi besar diberbagai aspek kehidupan. Waduk biasanya dibangun untuk beberapa tujuan, sperti pembangkit listrik tenaga air, irigasi atau pengendali banjir.

Waduk Cirata terbentuk dari adanya genangan air selas $66.033 .466 \mathrm{~m}^{2}$ akibat pembangunan waduk yang membendung Sungai Citarum, genagan waduk tersebut tersebar di 3 kabupaten, yaitu Kabupaten Cianjur, Bandung dan Purwakarta. Genagan air terluas berada di Kabupaten Cianjur dengan luas 29.603.299 $\mathrm{m}^{2}$, yang kemudian dimanfaatkan untuk kegiatan perikanan air tawar dan kegiatan pariwisata.

Budidaya ikan dalam keramba jaring apung (KJA) di tiga waduk di Jawa
Barat berkembang pesat. Pada tahun 1999 sudah mencapai 21.872 unit di waduk Saguling dan Cirata serta 2.194 unit (1998) (Krismono \& Wahyudi, 2001).

Ikan mas (Cyprinus carpio) merupakan salah satu jenis ikan yang bernilai ekonomis. Ikan ini telah memasyarakat dan menduduki produksi terbesar untuk jenis ikan budidaya air tawar di Indonesia. Ikan mas dapat dibudidayakan dengan berbagai system antara lain: sistem air deras, keramba, jaring terapung dan lainnya. Oleh karena itu, banyak petani ikan yang lebih memilih membudidayakan ikan mas baik dalam skala kecil maupun besar.

\section{Rumusan Masalah}

Kawasan waduk cirata memiliki luas $71.112 .824 \mathrm{~m}^{2}$ terdiri dari 5.081.358 $\mathrm{m}^{2}$ wilayah daratan dan $66.031 .466 \mathrm{~m}^{2}$ wilayah perairan. Fungsi utama waduk adalah sebagai pembangkit tenaga listrik, selain itu terdapat fungsi lain seperti irigasi pertaian, pengendalian banjir, perikanan konservasi air, dan pariwisata. Pembangunan dan pengelolaan Waduk Cirata akan menghasilkan nilai manfaat yang besar terutama kegiatan perikanan, 
dalam hal ini pemerintah memberdayakan dan memanfaatkan keberadaan waduk untuk kepentingan masyarakat agar dapat meningkatkan perekonomian dan kesejahteraan. Kegiatan perikanan yang diusahakan di Waduk Cirata adalah kegiatan usaha budidaya ikan di keramba jaring apung. Komoditas usaha budidaya ikan di keramba jaring apung di Waduk Cirata didominasi oleh komoditas ikan mas.

Kegiatan pembesaran ikan di jaring apung semakin diminati oleh masyarakat sekitar. Untuk menjamin kenyamanan dalam berusaha dibutuhkan pengetahuan tentang kelayakan usaha pembesaran ikan mas di keramba jaring apung. Untuk mengetahui kelayakan usaha perlu diadakan penelitian yang dapat mengetahui kelayakan usaha tersebut, dan dikemukakan dalam rumusan masalah, yakni "Berapa tingkat kelayakan usaha pembesaran ikan mas di dalam keramba jaring apung di Waduk Cirata Kabupaten Cianjur Propinsi Jawa Barat.

\section{Tujuan Penelitian}

Penelititan ini bertujuan untuk menghitung kelayakan usaha pembesaran ikan mas dalam keramba jaring apung di Waduk Cirata Kabupaten Cianjur Propinsi Jawa Barat.

\section{METODE PENELITIAN}

\section{Waktu dan Tempat}

Penelitian ini dilakukan di Waduk Cirata Kabupaten Cianjur Propinsi Jawa Barat. pada bulan Oktober -November 2008.

\section{Metodologi}

Metode yang digunakan dalam penelitian ini adalah metode survey.

Tabel 1. Daftar Nama dan Jumlah Pemilik Jaring

\begin{tabular}{|c|l|c|}
\hline No & Nama & Jumlah Jaring (kantong) \\
\hline 1 & Ade & 2 \\
2 & Imron & 2 \\
3 & Baban & 4 \\
4 & Icang & 4 \\
5 & Lukman & 4 \\
6 & Puji & 4 \\
7 & Uka & 4 \\
8 & Cecep & 8 \\
9 & Endang & 8 \\
10 & Uce & 8 \\
11 & Yayan & 8 \\
12 & Doni & 20 \\
13 & Tedi & 20 \\
\hline
\end{tabular}

\section{Jenis, Sumber Data dan Teknik Pengambilan Data}

Data yang dikumpulkan dalam penelitian ini adalah data primer dan data skunder. Data primer adalah data yang diperoleh langsung dari sumbernya. Sedangkan data sekunder berasal dari data pada instansi-instansi terkait.. Untuk pengambilan data primer dilakukan dengan menggunakan teknik wawancara menggunakan kuesioner. Sedangkan untuk data sekunder diambil melalui data yang tersedia pada instansi terkait 


\section{Teknik Sampling}

Lokasi pengambilan sampel untuk anggota kelompok adalah di Waduk Cirata Kabupaten Cianjur Propinsi Jawa Barat. Dalam penelitian ini sampel dimabil menggunakan tenik acak sederhanan (simple Random).

\section{Metode Analisis Data}

\section{a. Analisis Deskriptif}

Analisis deskriptif dilakukan untuk melihat aspek-aspek yang meliputi aspek-aspek teknik dan teknologi, aspek pasar dan pemasaran, aspek manajemen, aspek hukum, aspek sosial dan lingkungan. Data tersebut akan diambil menggunakan kuisioner dan diolah secara deskriftif.

Penelaahan tentang kelayakan usaha pembesaran ikan mas dalam keramba jaring terapung di Waduk Cirata Cianjur seperti telah diuraikan terdahulu menggunakan metode penelitian deskriptif. metode deskriptif ini bertujuan untuk mengembangkan sifat sesuatu yang tengah berlangsung pada saat riset dilakukan dan memeriksa sebab-sebab dan suatu gejala tertentu. sedang berlangsungnya proses riset.

- Metode Deskriptif, minimal $10 \%$ populasi, untuk populasi relatif kecil minimal $20 \%$ populasi.

- Metode Deskriptif Korelasional minimal 30 subyek.

Teknik pengambilan sampel yang digunakan adalah purpossive sampling yaitu suatu teknik pengambilan sampel dengan berdasarkan pada suatu pertimbangan tertentu yang dibuat oleh penelitian sendiri.

\section{b. Analisis Ekonomi Usaha KJA}

Analisis Ekonomi dilakukan untuk mengetahui apakah kegiatn usaha KJA di waduk Cirata menguntungkan atau layak siusahakan dari segi finansilanya.

\section{Revenue-Cost ratio (R/C)}

Perbandingan antara penerimaan dan pengeluaran biaya. Bila $\mathrm{R} / \mathrm{C}$ lebih dari satu dianggap layak, R/C kurang dari satu dianggap tidak layak, $\mathrm{R} / \mathrm{C}=$ satu (Trade Off) dapat dilaksanakan atau tidak tergantung keputusan dari pihak yang akan melaksanakan usaha.

\section{Break Event Point (BEP)}

Merupakan suatu alat ukur untuk mengetahui tingkat peluang pokok dimana usaha berada pada titik nol yaitu tidak dalam keadaan rugi dan tidak dalam keadaan untung. Penentuan BEP biasa dilakukan dalam bentuk unit atau rupiah dengan rumus sebagai berikut :

$$
\begin{aligned}
\text { BEP(Unit }) & =\frac{\text { Total Biay a Tetap }}{\text { Harga Jual }- \text { Biay a Variabel per Unit }} \\
\text { BEP(Rupiah) } & =\frac{\text { Total Biay a Tetap }}{1-\left(\frac{\text { Biay a Variabel per Unit }}{\text { Harga Jual }}\right)}
\end{aligned}
$$

\section{Payback Period}

Payback period (PP) adalah suatu periode yang di perlukan untuk menutup kembali pengeluaran investasi dengan menggunakan aliran kas.

Rumus :

$$
\mathrm{PP}=\frac{\text { Nilai Investas }}{\substack{\text { Tahun Kas Masuk } \\ \text { Bersih }}} \times 1
$$

\section{Internal Rate of Return (IRR)}

Metode ini digunakan untuk mencari tingkat bunga yang menyamakan nilai sekarang dari arus kas yang diharapkan dimasa akan dating atau penerimaan ks, dengan pengeluarana investasi awal. 


$$
\mathrm{I}_{\mathrm{O}}=\sum_{\mathrm{t}=1}^{\mathrm{n}} \frac{\mathrm{CF}_{\mathrm{t}}}{(1+\mathrm{IRR})^{\mathrm{t}}}
$$

Keterangan :

$$
\begin{aligned}
\mathrm{t} & =\text { tahun ke } \\
\mathrm{N} & =\text { jumlah tahun } \\
\mathrm{I} & =\text { nilai investasi awal } \\
\mathrm{CF} & =\text { arus kas bersih } \\
\mathrm{IRR} & =\text { tingkat bunga yang dicari } \\
& \text { harganya }
\end{aligned}
$$

\section{HASIL DAN PEMBAHASAN}

Berdasarkan hasil wawancara dengan para pembudidaya sebanyak 13 orang yang terdiri dari pemilik jaring dengan variasi pemilikan sebanyak 2 kantong, 4 kantong, 8 kantong, dan 20 kantong. Diperoleh data-data yang selanjutnya dituangkan dalam analisa usaha mulai dari penelitian 2 kantong, 4 kantong, 8 kantong, dan yang ekstrim sebanyak 20 kantong. Adapun analisa usaha yang tersusun terdapat pada Tabel 2 .

Tabel 2. Analisis Usaha Pembesaran Ikan Mas Dalam Keramba Jaring Apung

\begin{tabular}{|l|l|r|r|r|r|}
\hline $\begin{array}{c}\text { N } \\
\mathbf{0}\end{array}$ & \multicolumn{1}{|c|}{$\mathbf{2}$} & $\mathbf{4}$ & $\mathbf{8}$ & \multicolumn{1}{c|}{$\mathbf{2 0}$} \\
& Kantong & & & \\
\hline 1 & Uraian & & & & \\
& & $10.200 .000,0$ & $19.400 .000,0$ & $52.800 .000,00$ & $104.000 .000,00$ \\
2 & Biaya Tetap & 0 & 0 & & \\
3 & Biaya tidak Tetap & $17.293 .333,33$ & $4.020 .000,00$ & $6.040 .000,00$ & $13.666 .666,66$ \\
& & $0.000,0$ & $35.040 .000,0$ & $70.080 .000,00$ & $175.200 .000,00$ \\
4 & Total biaya (2+3) & $20.813 .333,3$ & $39.060 .000,0$ & & \\
& & 3 & 0 & $76.120 .000,00$ & $188.866 .666,66$ \\
5 & Penerimaan & $22.500 .000,0$ & $45.000 .000,0$ & & \\
& & 0 & 0 & $90.000 .000,00$ & $225.000 .000,00$ \\
6 & Laba (5-4) & $1.686 .666,67$ & $5.940 .000,00$ & $13.880 .000,00$ & $36.144 .333,34$ \\
7 & R/C Ratio & 1,08 & 1,15 & 1,18 & 1,19 \\
8 & BEP (Unit) & $1.190,22$ & 1.447 & $2.183,13$ & $6.808,14$ \\
& BEP (Rupiah) & 14.969 .695 & 18.088 .553 & 27.289 .124 & 85.101 .790 \\
9 & PP (Periode) & 6,05 & 3,26 & 3,80 & 2,88 \\
10 & IRR (\%) /tahun & 32,41 & 60,83 & 72,94 & 76,53 \\
\hline
\end{tabular}

Tampilan data analisa usaha mulai skala usaha 2 kantong, 4 kantong, 8 kantong, dan 20 kantong, dilihat dari segi R/C Ratio masing-masing skala usaha menunjukan angka sebagai berikut : 2 kantong $=1,08$; 4 kantong $=1,15 ; 8$ kantong $=1,18$; dan 20 kantong $=1,19$. masing-masing angka mempunyai arti bahwa berdasarkan perbandingan penerimaan terhadap pembiayaan usaha, semua skala usaha masih layak diusahakan dimana masing- masig angka memiliki ratio > 1 yang berarti dari setiap Rp. 1,- biaya yang dikeluarkan masih memberikan keuntungan yaitu skala 2 kantong sebesar Rp. 0,08,- ; skala 4 kantong Rp. 0,15,- ; skala 8 kantong Rp. 0,18,- ; dan skala 20 kantong Rp. 0,19,-.

Dari keempat skala usaha, angka keuntungan menunjukan kenaikan secara linier dan keuntungan yang tertinggi terjadi pada skala 20 . hal ini bila dilihat 
dari struktur biaya yang juga meningkat secara linier mengandung arti bahwa keuntungan yang besar diperoleh dari penanaman modal yang besar pula, hal ini sesuai dengan prinsip ekonomi saat ini.

Selanjutnya dilihat dari tampilan kemampuan mengembalikan investasi (PP) angka tertinggi terdapat pada skala 2 kantong yaitu 6,05 yang berarti investasi baru dapat dikembalikan dalam waktu 6,05 periode sedangkan angka terendah terdapat pada skala usaha 20 kantong yaitu 2,88 yang berarti investasi dapat dikembalikan dalam waktu 2,88 periode. Bila dikaitkan dengan R/C Ratio menunjukkan bahwa semakin besar angka R/C Ratio maka akan semakin kecil angka PP-nya.

Tampilan angka pada analisis IRR, skala 2 kantong $=32,41 \%, 4$ kantong $=60,83 \%, 8$ kantong $=72,94 \%, 20$ kantong $=76,53 \%$, angka-angka tersebut menggambarkan kenaikan secara linier seperti halnya pada angka R/C Ratio. Bila keduanya dikaitkan dapat diartikan bahwa apabila angka R/C Ratio rendah, IRR-pun rendah dan apabila $\mathrm{R} / \mathrm{C}$ Ratio tinggi IRR-pun tinggi.

Dilihat dari ketiga unsur analisa yaitu R/C Ratio, PP, dan IRR, dapat ditarik kesimpulan bahwa usaha pembesaran ikan mas dalam jaring apung baik skala usaha 2 kantong, 4 kantong, 8 kantong, maupun 20 kantong yang masing-masing masih menghasilkan keuntungan yang berarti usaha ini masih layak diusahakan, namun untuk mendapatkan keuntungan yang besar memerlukan modal yang besar pula.

\section{KESIMPULAN DAN SARAN}

\section{Kesimpulan}

Berdasarkan tampilan data analisa usaha dilihat dari laba yang diperoleh serta angka-angka perolehan pada R/C Ratio, Payback Period, dan Interval Rat at Riten, menunjukkan bahwa usaha pembesaran ikan mas dalam jaring apung saat sekarang masih layak diusahakan dengan asumsi keuntungan mengikuti prinsip ekonomi yang berlaku yaitu untuk mendapatkan keuntungan yang besar diperlukan modal yang besar pula.

\section{Saran}

1. Kajian ini masih perlu ditindak lanjuti dimasa-masa yang akan datang sesuai dengan kondisi perekonomian baik nasional maupun internasional.

2. Untuk membantu lebih layaknya usaha pada pembudidaya dengan modal kecil sehingga lebih bisa bertahan perlu adanya perhatian pemerintah dalam pengendalian harga pakan/ pelet dan harga jual ikan serta pembukaan peluang pasar seluas-luasnya.

\section{DAFTAR PUSTAKA}

Anonimous. 2005. Jurnal Penelitian Perikanan Indonesi Volume 11 Nomor 1 Tahun 2005.

Efendi Irzal. 2004. Pengantar Akuakultur. Penebar Swadaya. Jakarta.

Husein Umar (2000). Riset Sumberdaya Manusia. PT. Gramedia Pustaka Utama, Jakarta.

Krismono dan N.A. Wahyudi. 2001. Analisis kebijakan pengelolaan KJA sebagai salah satu pengelolaan danuau atau waduk. Analsis Kebijakan Pengembangan

Perikanan. Pusat Riset Pengolahan Produk dan Sosial Ekonomi Kelautan dan Perikanan, p. 75-85.

Linga Pinus. 1985. Ikan Mas Kolam Air Deras. Penebar Swadaya. Jakarta.

Imade Pidarta (1986). Pemikiran Tentang Supervisi Pendidikan Sarana Press. 
Manasse Malo, dkk (2000). Metode Penelitian Sosial. Universitas Terbuka, Jakarta.

Nazir, M. 2005. Metoda Penelitian. Ghalia Indonesia. Bogor

Nawawi H. 1990. Metode Penelitian Bidang Sosial. Gajah Mada University Press. Yokyakarta.

Nuraeni I, dkk. 2005. Manajemen Agribisnis. Sekolah Tinggi Penyuluhan Pertanian. Bogor.

Rochdianto, Agus. 1986., "Selayang Pandang Mengenal Ikan Air Tawar". Sinar Tani. Jakarta.
Santoso, Budi. 1995. Petunjuk Praktis Budidaya Ikan Mas. Kanisius.Yogyakarta.

Saputra H. 1988. Membuat dan Membudidayakan Ikan dalam Kantong Jaring Apung. CV. Simplex. Jakarta

Tim Lentera, 2002. Pembesaran Ikan Mas dikolam air deras. Penerbit PT Agro Media Pustaka. Tangerang

Umar Husein. 2000. Studi Kelayakan Bisnis Manajemen, Metode dan Kasus. Gramedia Pustaka Utama. Jakarta. 